\title{
HYBRID MICROSURGICAL AND ENDOVASCULAR APPROACH IN THE TREATMENT OF MULTIPLE CEREBRAL ANEURYSMS: AN ILLUSTRATIVE CASE SERIES IN CORRELATION WITH LITERATURE DATA
}

\author{
Krešimir Rotim ${ }^{1,2,3}$, Vladimir Kalousek ${ }^{4}$, Bruno Splavski ${ }^{1,2,3,5}$, Sanja Tomasovićc ${ }^{2,6}$ and Ante Rotim ${ }^{1}$ \\ ${ }^{1}$ Department of Neurosurgery, Sestre milosrdnice University Hospital Centre, Zagreb, Croatia; \\ ${ }^{2}$ Josip Juraj Strossmayer University of Osijek, Faculty of Medicine, Osijek, Croatia; \\ ${ }^{3}$ University of Applied Health Sciences, Zagreb, Croatia; \\ ${ }^{4}$ Department of Radiology, Sestre milosrdnice University Hospital Centre, Zagreb, Croatia; \\ ${ }^{5}$ Josip Juraj Strossmayer University of Osijek, Faculty of Dental Medicine and Health, Osijek, Croatia; \\ ${ }^{6}$ Department of Neurology, Sveti Duh University Hospital, Zagreb, Croatia
}

\begin{abstract}
SUMMARY - Contemporary cerebral aneurysm treatment has advanced due to the expansion of microsurgical and endovascular techniques having different advantages and restraints. However, some aneurysms cannot be effectively treated by a single method alone due to their specific anatomy, location, complexity, and/or multiplicity. Subsequently, multiple aneurysms sometimes necessitate a hybrid strategy integrating both methods. The study aims were to discuss indications, possibilities, and challenges of a hybrid strategy in the decision making and treatment of multiple intracranial aneurysms. A single-institution illustrative case series of multiple intracranial aneurysm patients treated by a hybrid approach was analyzed and management outcome discussed and correlated with literature data. Following the treatment, both patients from our case series recovered well, having complete and stable aneurysmal occlusion with no relapse and no postoperative procedure-related complications or long-lasting neurological symptoms. In conclusion, a hybrid approach is advised as a treatment option for multiple cerebral aneurysms when a single modality is insufficient to bring satisfactory results. It may be a suitable and safe addition to an assortment of treatments pledging clinical improvement and enabling positive management outcome in patients with ruptured and non-ruptured multiple cerebral aneurysms.
\end{abstract}

Key words: Cerebral aneurysm, multiple; Microsurgical clipping; Endovascular treatments; Hybrid approach; Management outcome

\section{Introduction}

Management options for brain aneurysms have considerably progressed in recent years owing to the outstanding developments in microsurgical and endovascular techniques ${ }^{1-4}$. However, both techniques have been recognized as mutually divergent, express-

Correspondence to: Bruno Splavski, $M D, P h D$, Department of Neurosurgery, Sestre milosrdnice University Hospital Centre, Vinogradska c. 29, HR-10000 Zagreb, Croatia

E-mail: splavuno@gmail.com

Received February 2, 2021, accepted February 26, 2021 ing separate advantages, as well as different restrictions. Therefore, the controversy on what strategy to choose in the treatment of multiple intracranial aneurysms still remains ${ }^{5}$. A substantial number of such aneurysms may be occluded using different endovascular techniques instead of microsurgical clipping ${ }^{6}$. However, the optimal treatment modality has yet to be confirmed.

Microsurgical clipping of intracranial ruptured and non-ruptured aneurysms has long been the gold standard, yet expansions in endovascular techniques have challenged this rapidly. Nowadays, such techniques are 
widely accepted as a possible treatment modality option for selected single, multiple, as well as distal branch intracranial aneurysms ${ }^{7}$. Nevertheless, some aneurysms cannot be successfully treated by a single technique alone due to their particular anatomy, location, complexity and multiplicity. Therefore, determination of aneurysm treatment should be a multidisciplinary decision of highly experienced personnel based on characteristics of the aneurysm and individualities of the patient ${ }^{8,9}$. Consequently, treatment of multiple aneurysms sometimes requires a hybrid combination strategy of both methods ${ }^{10,11}$.

In this paper, we discuss indications and contemporary possibilities of a hybrid microsurgical and endovascular strategy in the treatment of multiple intracranial aneurysms, addressing specifics and particular challenges of this combined management approach. It is based on the illustrative case series report, literature review and our single-institution experience gained in the dual treatment of complex and multiple cerebral aneurysms during the last few years.

\section{Material and Methods}

The illustrative case series of two patients with multiple ruptured and non-ruptured cerebral aneurysms of various intracranial locations was analyzed. The presence of multiple intracranial aneurysms was confirmed by standardized neuroradiological diagnostic protocol consisting of initial brain computerized tomography (CT), three-dimensional (3D) CT cerebral angiography (CTA), and digital subtraction panangiography (DSA) of cerebral vessels.

Patients' gender and age were recorded, and their presenting clinical condition was assessed by HuntHess (HH) scoring and World Federation of Neurosurgical Societies (WFNS) scale. The number and intracranial location of aneurysms, timing and technique of aneurysmal treatment were specified. Management outcome was assessed by the Glasgow Outcome ScaleExtended (GOSE) at hospital discharge and by modified Rankin Score (mRS) at 6-month follow-up.

Effectiveness and safety end-points of the management applied were confirmed by independently examined clinical and angiographic post-procedural followup at 6 months.

Hunt-Hess scoring is a clinical grading system based on the intensity of meningeal inflammatory re- action, the severity of neurological deficit, the level of arousal, and the presence of associated diseases ${ }^{12}$.

The WFNS scale for grading patients with aneurysmal subarachnoid hemorrhage (SAH) uses Glasgow Coma Scale (GCS) score as an input to assess patient clinical condition, and evaluates the presence/absence of focal neurological deficits ${ }^{13}$.

The 8-point GOSE epitomizes a descriptive outcome measure allowing greater differentiation between the levels of postoperative recovery, which splits outcome categories of severe disability, moderate disability, and good recovery into lower and upper groupings ${ }^{14}$.

The 6-point $\mathrm{mRS}$ typifies an additional management outcome measure for evaluating the patient degree of disability or dependence in their daily activities ${ }^{15}$.

The patient presenting clinical condition was considered stable if $\mathrm{HH}$ grades I and II, and WFNS grade I were documented. The outcome was presumed to be favorable if GOSE 6-8 (upper or lower good recovery) and mRS 0-2 (no symptoms, no significant disability or slight disability) were recorded.

The pre-procedural antiplatelet dual therapy was avoided. It was regularly applied in both patients after the dual procedure was completed.

The research was conducted in line with the respective ethical principles and responsibility, and in full compliance with relevant legislation. A written informed consent for publication of their clinical details and clinical images was obtained from the patients.

\section{Results}

The middle cerebral artery (MCA), internal carotid artery (ICA), anterior choroidal artery (AChA) and basilar artery (BA) tip aneurysms were observed. Out of five aneurysms recorded, two were ruptured and accompanied with SAH. The presenting clinical condition assessed by $\mathrm{HH}$ grading system and WFNS scale was considered stable (HH grades I and II; WFNS grade I) in both patients. The outcome at hospital discharge assessed by GOSE pointed to good recovery (GOSE 6-8), while the outcome at 6-month followup assessed by $\mathrm{mRS}$ indicated no significant disability (mRS 0-1). Angiographic studies performed at follow-ups by an independent radiologist confirmed complete and stable aneurysmal occlusion with no radiological signs of aneurysm recurrence. In both pa- 

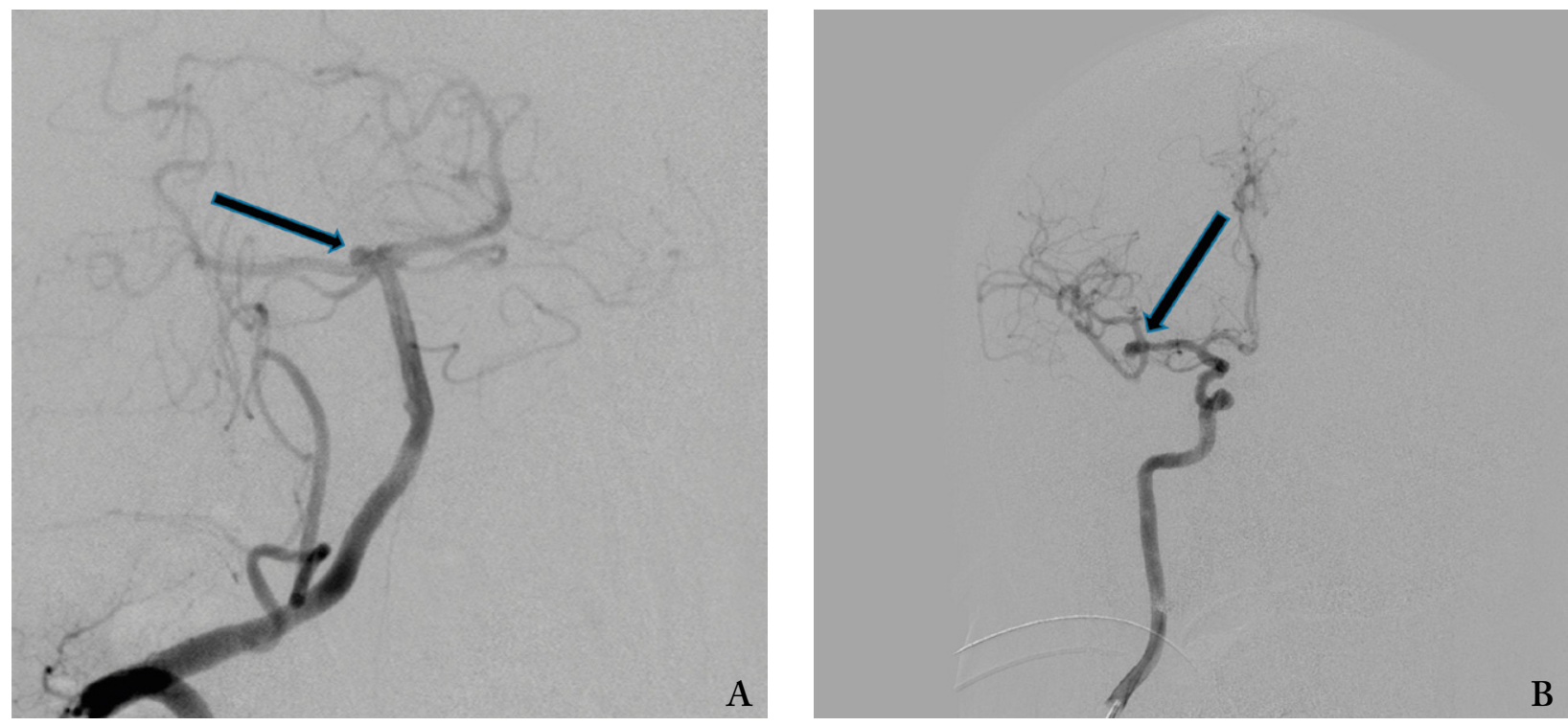

Fig. 1. Cerebral vessel DSA showing unruptured aneurysm of the BA tip (A), and ruptured aneurysm of the right $M C A(B)$ (arrows).

tients, further clinical and neuroradiological check-up was advised.

\section{Illustrative Case Reports}

\section{Case 1}

A 64-year-old male presented with severe headache and nuchal rigidity (HH II; WFNS grade I). No history of high blood pressure, smoking and/or major comorbidities was recorded. Urgent diagnostics was performed showing diffuse SAH on brain CT scanning. Additional diagnostics was done including DSA, which showed a non-ruptured aneurysm of BA tip and ruptured aneurysm of the right MCA at bifurcation (Fig. 1 A, B).

The patient underwent one-stage combined procedure within the first 48 hours of admission. Selective coiling of the BA aneurysm was performed first, followed by selective clipping of the right MCA aneurysm by right-sided pterional craniotomy using intraoperative transcranial Doppler (TCD) and fluorescein angiography to check the main artery blood flow. After the procedure, the patient was asked to take $75 \mathrm{mg}$ of clopidogrel per day for 3 months, and $325 \mathrm{mg}$ of aspirin per day for 6 months.

Post-procedural cerebral vessel DSA showed complete occlusion of the coiled BA tip aneurysm (Fig. 2
A). Postoperative native brain CT showed metal artifacts after right-sided pterional craniotomy and correct selective clip placement with no signs of intracranial hemorrhage and/or cerebral ischemia (Fig. 2 B).

The patient was discharged without neurological deficit and made lower good recovery (GOSE 7). At 6-month follow-up, he was able to carry out all his usual daily activities, having no significant disability despite complaining of some minor symptoms such as occasional mild diffuse headache (mRS 1). Angiographic check-up showed proper clip and coil placement and no signs of residual aneurysms.

\section{Case 2}

A 60-year-old female presented with mild headache (HH I; WFNS grade I). No comorbidities besides arterial hypertension were recorded on admission. Diffuse SAH mainly located at the right sylvian fissure, basal cisterns and right frontal and parietal lobe was confirmed by brain CT. Additional diagnostics consisting of 3D CTA (Fig. 3) and cerebral DSA showed the existence of three aneurysms. Two nonruptured aneurysms were located on the left AChA and left MCA, while the third one was the right ophthalmic segment ICA aneurysm, which was bleeding.

The patient underwent immediate one-stage combined endovascular and microsurgical procedure. Se- 

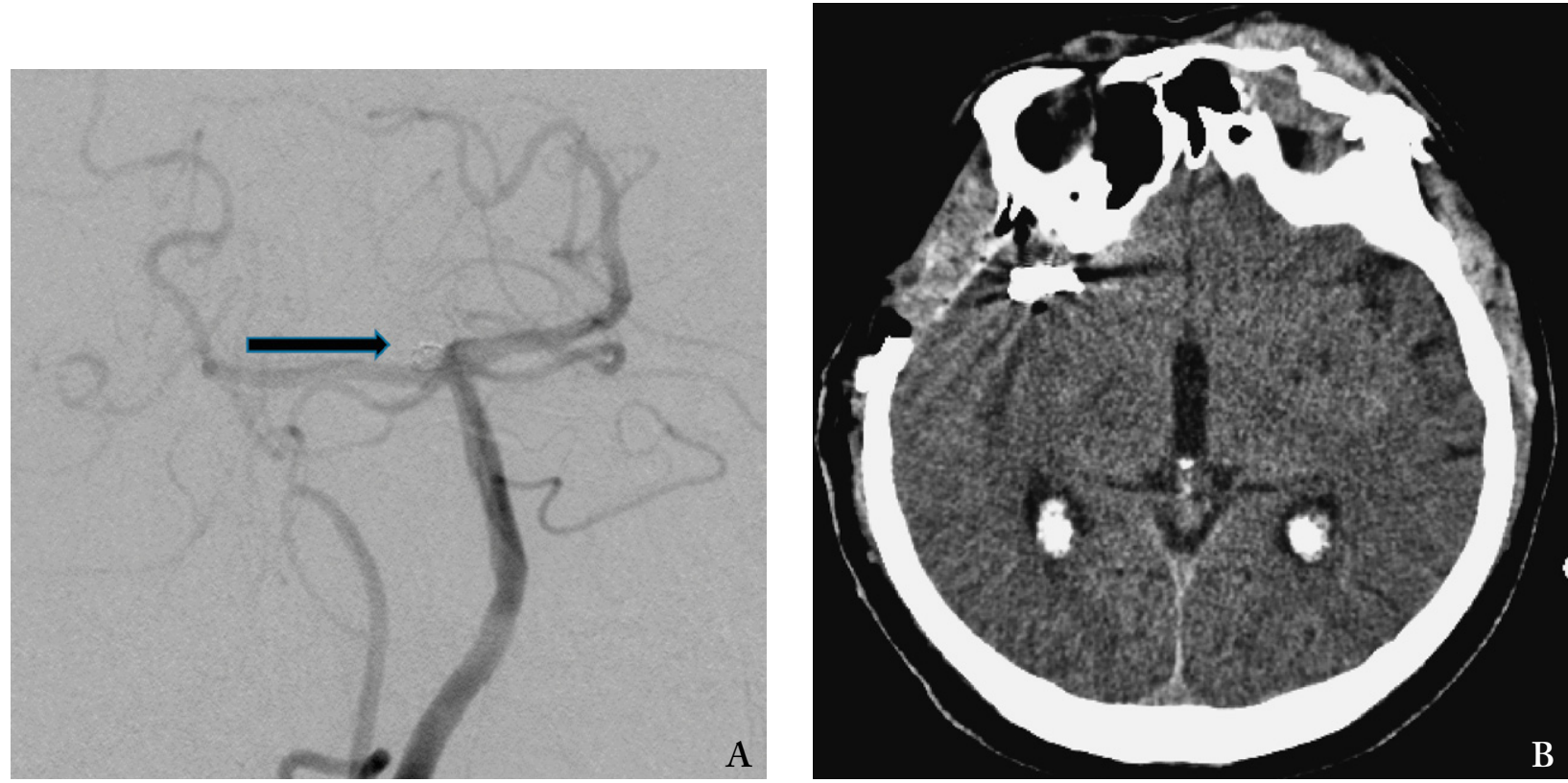

Fig. 2. Cerebral vessel DSA showing coiled aneurysm of the BA tip (arrow) (A); postoperative native brain CT showing metal artifacts after right-sided pterional craniotomy and clipping of ruptured aneurysm of the right $M C A$ with no signs of intracranial hemorrhage and/or cerebral ischemia (B).

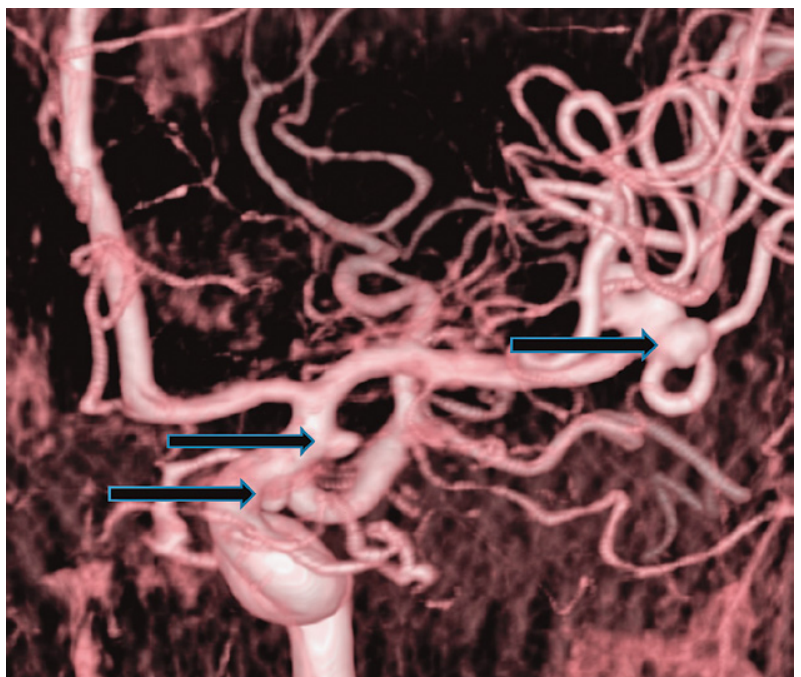

Fig. 3. Brain 3D CT angiography showing 3 remote aneurysms: the left $A C h A$ and left $M C A$ unruptured aneurysms, and the right ICA (ophthalmic segment) aneurysm, which was ruptured (arrows).

lective coiling of the right ruptured ICA aneurysm on the ophthalmic segment was performed first, which was confirmed by post-procedural DSA (Fig. 4). Soon afterwards, selective clippings of the opposite side un-

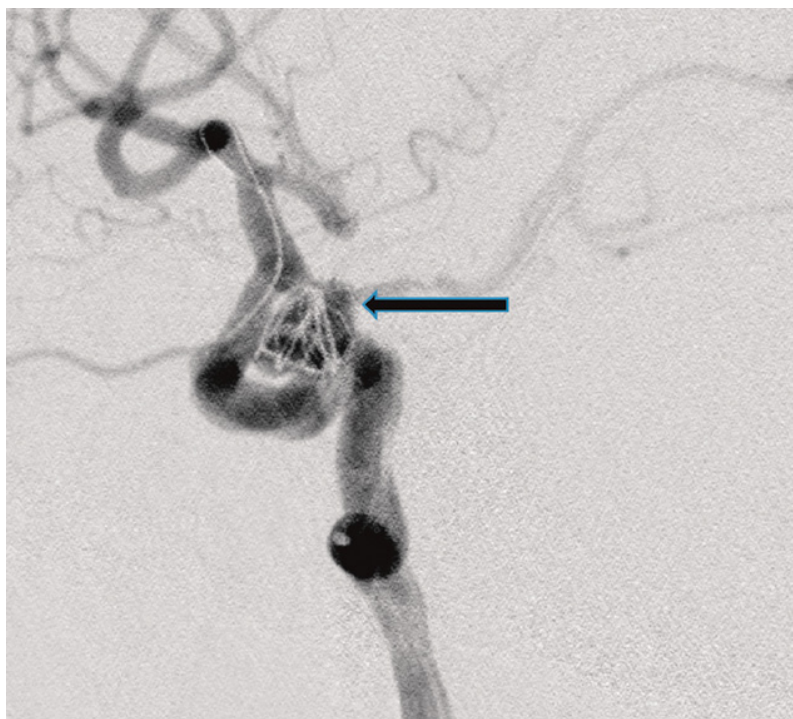

Fig. 4. Cerebral DSA showing coiling of the right ophthalmic segment ICA ruptured aneurysm (arrow) during a one-stage hybrid procedure.

ruptured aneurysms of the left $\mathrm{AChA}$ and left MCA were performed (Fig. 5 A, B).

The patient was discharged without neurological deficits, having lower good recovery (GOSE 7). At 

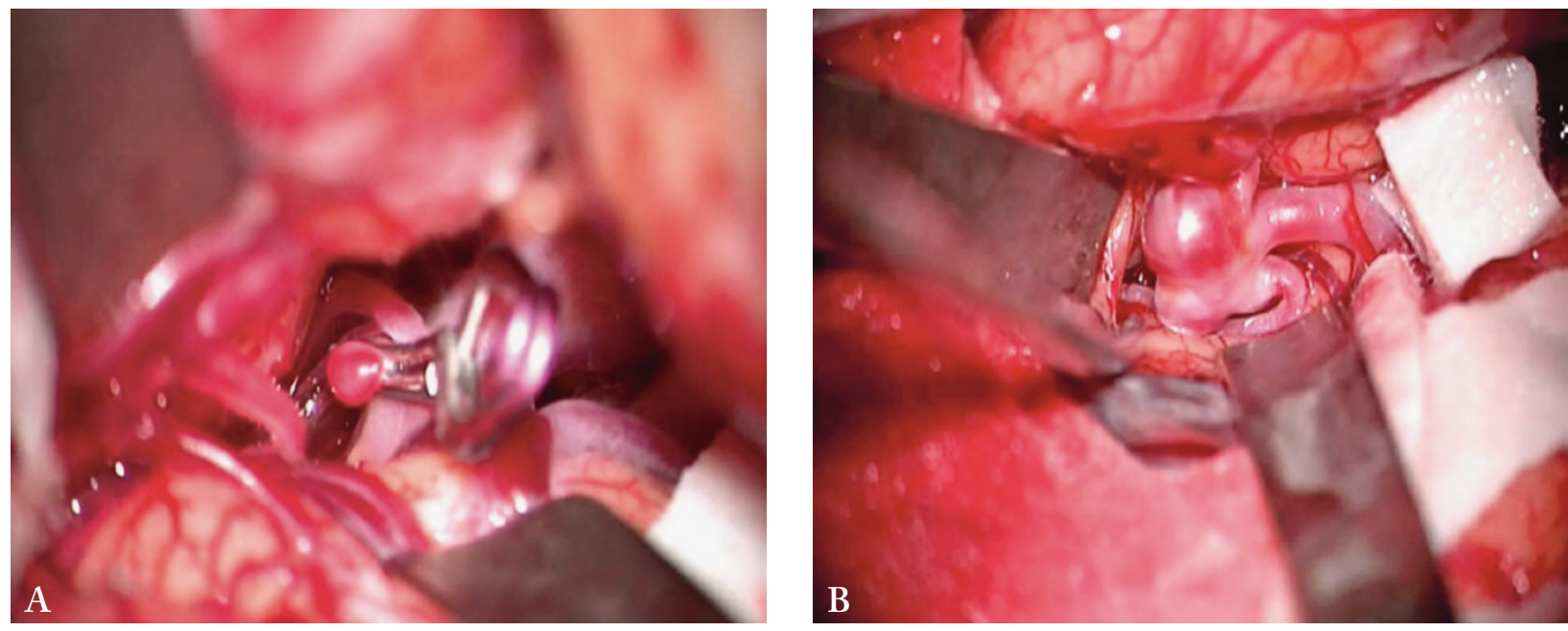

Fig. 5. Microsurgical intraoperative photo showing clipping of the left AChA aneurysm (A), and preparing for clipping of the left $M C A$ aneurysm (B).

6-month follow-up, she was able to carry out her usual daily activities, having no significant disability (mRS 1). Following the procedure, she received quotidian dual antiplatelet therapy consisting of $75 \mathrm{mg}$ of clopidogrel for 3 months and $325 \mathrm{mg}$ of aspirin for 6 months.

Follow-up DSA revealed complete and stable aneurysm occlusion with no residual contrast filling.

\section{Discussion}

Multiple cerebral aneurysms may be detected in up to one-third of patients having intracranial cerebral aneurysms ${ }^{16}$. When such aneurysms are concerned, the natural history of the disease has led to an agreement that all aneurysms should be treated in one-stage, if technically possible ${ }^{5}$. However, all aneurysms should not be necessarily treated in the same way, since there is no ideal treatment option suitable for all conditions. Hence, patient clinical condition, as well as the size and location of the aneurysm are the factors of great influence on the appropriate selection of treatment timing and appropriate management strategy, which are important for outcome ${ }^{17}$. Accordingly, we followed the same rules in selecting management for our patients.

The type of treatment approach, as well as the time of surgery and outcome have been extensively discussed in relevant neurosurgical literature ${ }^{18-21}$. When multiple aneurysms accompanied by $\mathrm{SAH}$ indicating an aneurysm rupture are concerned, it is also essential to determine which of them happened to rupture, since it is a decisive information in preparing the most effective management strategy. Out of five aneurysms of different intracranial locations recorded in our patients, three were non-ruptured, and two were ruptured and accompanied by SAH, demanding immediate treatment.

Currently, different endovascular techniques are at disposal for multiple aneurysms, as well as for BA tip aneurysm occlusion regardless of their rupture status ${ }^{22}$. Nevertheless, some authors advocate one-stage, as well as hybrid surgery for all multiple intracranial aneurysms, since the surgical risk for such aneurysms is only slightly higher than for single aneurysms ${ }^{5,18}$. We tried to execute a similar strategy in our patients.

Clipping of multiple ipsilateral MCA aneurysms still remains a dominant procedure having low morbidity-mortality and recurrence rates ${ }^{4,6}$. However, expanding endovascular techniques may offer more robust tools for these aneurysms $\mathrm{s}^{23}$, as well as for those less suitable for surgical clipping, where endovascular methods have been shown to be a well-grounded alternative modality ${ }^{24}$. Another advantage of endovascular approach is better determination of the site of rupture and elimination of misdiagnosing/false localization ${ }^{25,26}$. Furthermore, all aneurysms (regardless of their rupture status) may be simultaneously occluded in a single endovascular act, thus avoiding not treating the bleeding one $^{27,28}$. Although ischemic and hemorrhagic complications do occur more frequently in comparison to 
clipping $^{25}$, endovascular treatment may be a particularly suitable method for this high-risk aneurysm type. Hence, endovascular treatment of multiple intracranial aneurysms is recommended as the management option for the contralateral aneurysms and those technically difficult for clipping. Even though most intracranial aneurysms can be successfully treated by microsurgical or endovascular technique alone ${ }^{29}$, a subgroup of $\mathrm{pa}^{-}$ tients with complex and multiple aneurysms may require a combined approach strategy ${ }^{30}$. Any intracranial aneurysm treatment should be focused on complete aneurysmal occlusion, while parent arterial flow should remain patent ${ }^{31}$. To achieve this, a combined approach employing both microsurgical and endovascular techniques may be beneficial, since it minimizes the risk and maximizes treatment efficacy and outcome. Following such a stance, we did not record any ischemic and hemorrhagic procedure-related complications in our patients after a hybrid procedure.

One-stage endovascular coiling and microsurgical clipping of multiple remote aneurysms on the opposite side may be an option when the MCA aneurysm, which is amenable to clipping, and the opposite side aneurysm of difficult location suitable for coiling are encountered. Thus, microsurgical and endovascular techniques are complementary rather than competing $^{32}$, since a combining management strategy may have a positive effect on the outcome ${ }^{33}$. This was the case in our 3-aneurysm patient in whom coiling and clipping of multiple remote contralateral aneurysms was performed as one-stage procedure.

Considering the management outcome, less favorable prognosis for patients with multiple aneurysms is not well established $d^{5,18,34,35}$. However, significantly worse outcomes were observed in elderly patients with multiple aneurysms than in those with a single aneurysmal lesion ${ }^{36-38}$. Nevertheless, the outcome of our patients was favorable despite their relatively advanced age.

Bearing in mind our results and considering the literature, it appears that hybrid microsurgical and endovascular techniques may be successfully applied as a treatment strategy for multiple intracranial aneurysms bringing promising results. However, we believe that a particular treatment strategy has to be highly personalized and individually designed for each patient, enabling a favorable outcome.

In conclusion, a hybrid approach may be used as the management strategy when a single modality is insufficient to bring satisfactory results. It should be taken into consideration as an appropriate and safe adding to a variety of treatment options ensuring clinical improvement and facilitating successful management outcome in patients with ruptured and non-ruptured multiple cerebral aneurysms.

In the last part of this paper, certain limitations have to be addressed coming from its retrospective nature, small sample of patients in this illustrative case series, and relatively short follow-up period. Therefore, additional study is required to strengthen our findings.

\section{References}

1. O'Neill AH, Chandra RV, Lai LT. Safety and effectiveness of microsurgical clipping, endovascular coiling, and stent assisted coiling for unruptured anterior communicating artery aneurysms: a systematic analysis of observational studies. J Neurointerv Surg. 2017;9(8):761-5. doi: 10.1136/neurintsurg-2016012629.

2. Phan K, Huo YR, Jia F, Phan S, Rao PJ, Mobbs RJ, et al. Metaanalysis of stent-assisted coiling versus coiling-only for the treatment of intracranial aneurysms. J Clin Neurosci. 2016; 31:15-22. doi: 10.1016/j.jocn.2016.01.035.

3. Ruan C, Long H, Sun H, He M, Yang K, Zhang H, et al. Endovascular coiling $v s$ s surgical clipping for unruptured intracranial aneurysm: a meta-analysis. Br J Neurosurg. 2015;29(4): 485-92. doi: 10.3109/02688697.2015.1023771.

4. Smith TR, Cote DJ, Dasenbrock HH, Hamade YJ, Zammar SG, E1Tecle NE, et al. Comparison of the efficacy and safety of endovascular coiling versus microsurgical clipping for unruptured middle cerebral artery aneurysms: a systematic review and meta-analysis. World Neurosurg. 2015;84(4):942-53. doi: 10.1016/j.wneu.2015.05.073.

5. Vajda J. Multiple intracranial aneurysms: a high risk condition. Acta Neurochir (Wien). 1992;118:59-75. doi: 10.1007/BF01 400727.

6. van Dijk JM, Groen RJ, Ter Laan M, Rinck Jeltema J, Mooij JJA, Metzemaekers JDM. Surgical clipping as the preferred treatment for aneurysms of the middle cerebral artery. Acta Neurochir (Wien) 2011;153(11):2111-7. doi: 10.1007/s00701011-1139-6.

7. Rotim K, Splavski B, Kalousek V, Jurilj M, Sajko T. Endovascular management of intracranial aneurysms of distal arterial branches: illustrative case series and literature retrospection. Acta Clin Croat. 2020;59:712-20. doi: 10.20471/acc.2020. 59.04.18.

8. Connolly ES Jr, Rabinstein AA, Carhuapoma JR, Derdeyn CP, Dion J, Higashida RT, et al. Guidelines for the management of aneurysmal subarachnoid hemorrhage: a guideline for healthcare professionals from the American Heart Association/ American Stroke Association. Stroke. 2012;43(6):1711-37. doi: 10.1161/STR.0b013e3182587839. 
9. Bederson JB, Connolly ES Jr, Batjer HH, Dacey RG, Dion JE, Diringer MN, et al. Guidelines for the management of aneurysmal subarachnoid hemorrhage: a statement for healthcare professionals from a special writing group of the Stroke Council, American Heart Association. Stroke. 2009;40(3):994-1025. doi: 10.1161/STROKEAHA.108.191395.

10. Chung J, Shin YS. Multiple intracranial aneurysms treated by multiple treatment modalities. Neurosurgery. 2011;69(4): E1030-2. doi: 10.1227/NEU.0b013e31822a5280.

11. Marks MP, Steinberg GK, Lane B. Combined use of endovascular coils and surgical clipping for intracranial aneurysms. AJNR Am J Neuroradiol. 1995;16(1):15-8.

12. Hunt WE, Hess RM. Surgical risk as related to time of intervention in the repair of intracranial aneurysms. J Neurosurg. 1968;28:14-20. doi: 10.3171/jns.1968.28.1.0014.

13. Drake CG. Report of World Federation of Neurological Surgeons Committee on a universal subarachnoid hemorrhage scale. J Neurosurg. 1988;68:985-6. doi: 10.3171/jns.1988. 68.6.0985.

14. Wilson JTL, Pettigrew LEL, Teasdale GM. Structured interviews for the Glasgow Outcome Scale and the Extended Glasgow Outcome Scale: guidelines for their use. J Neurotrauma. 1997;15(8):573-85. doi: 10.1089/neu.1998.15.573.

15. Wilson JT, Hareendran A, Grant M, Baird T, Schulz UG, Muir $\mathrm{KW}$, et al. Improving the assessment of outcomes in stroke: use of a structured interview to assign grades on the modified Rankin Scale. Stroke. 2002;33(9):2243-6. doi: 10.1161/01. str.0000027437.22450.bd.

16. Rinne J, Hernesniemi J, Puranen M, Saari T. Multiple intracranial aneurysms in a defined population: prospective angiographic and clinical study. Neurosurgery. 1994;35(5):803-8. doi: 10.1227/00006123-199411000-00001.

17. Heiskanen O, Marttila I. Risk of rupture of a second aneurysm in patients with multiple aneurysms. J Neurosurg. 1970;32 (3):295-9. doi: 10.3171/jns.1970.32.3.0295.

18. Taki W, Sakai N, Suzuki H, PRESAT Group. Determinants of poor outcome after aneurysmal subarachnoid hemorrhage when both clipping and coiling are available: Prospective Registry of Subarachnoid Aneurysms Treatment (PRESAT) in Japan. World Neurosurg. 2011;76(5):437-45. doi: 10.1016/j. wneu.2011.04.026.

19. Mizoi K, Suzuki J, Yoshimoto T. Surgical treatment of multiple aneurysms: review of experience with 372 cases. Acta Neurochir (Wien). 1989;96:8-14. doi: 10.1007/BF01403489.

20. Nemoto M, Yasui N, Suzuki A, Sayama I. [Problems of surgical treatment for multiple intracranial aneurysms]. Neurol Med Chir (Tokyo). 1991;31(13):892-8. (in Japanese) doi: 10.2176/ nmc.31.892.

21. Orz Y, Osawa M, Tanaka Y, Kyoshima K, Kobayashi S. Surgical outcome for multiple intracranial aneurysms. Acta Neurochir (Wien). 1996;138(4):411-7. doi: 10.1007/BF01420303.

22. Kalousek V, Splavski B, Beroš V, Čulo B, Vrban F, Rotim A, Rotim K. Large aneurysm of basilar artery tip mimicking mid- brain tumor and causing unilateral obstructive hydrocephalus: a case report and a technical note. Acta Clin Croat. 2020;59: 166-72. doi: 10.20471/acc.2020.59.01.21.

23. Andaluz N, Zuccarello M. Recent trends in the treatment of cerebral aneurysms: analysis of a nationwide inpatient database. J Neurosurg. 2008;108:1163-9. doi: 10.3171/JNS/2008/108/ $6 / 1163$.

24. Santiago-Dieppa DR, Pannell JS, Khalessi AA. Endovascular and surgical options for ruptured middle cerebral artery aneurysms: review of the literature. Stroke Res Treat. 2014;2014: 315906. doi: 10.1155/2014/315906.

25. Shen X, Xu T, Ding X, Wang W, Liu Z, Qin H. Multiple intracranial aneurysms: endovascular treatment and complications. Interv Neuroradiol. 2014;20(4):442-7. doi: 10.15274/INR2014-10037.

26. Viñuela F, Duckwiler G, Mawad M. Guglielmi detachable coil embolization of acute intracranial aneurysm: perioperative anatomical and clinical outcome in 403 patients. J Neurosurg. 1997;86(3):475-82. doi: 10.3171/jns.1997.86.3.0475.

27. Hino A, Fujimoto M, Iwamoto Y, Yamaki T, Katsumori T. False localization of rupture site in patients with multiple cerebral aneurysms and subarachnoid hemorrhage. Neurosurgery. 2000;46:825-30. doi: 10.1097/00006123-200004000-00011.

28. Nehls RJ, Flom RA, Carter LP, Spetzler RF. Multiple intracranial aneurysms: determining the site of rupture. J Neurosurg. 1985,63:342-8. doi: 10.3171/jns.1985.63.3.0342.

29. Oh K, Lim YC. Single-session coil embolization of multiple intracranial aneurysms. J Cerebrovasc Endovasc Neurosurg. 2013;15(3):184-90. doi: 10.7461/jcen.2013.15.3.184.

30. Xavier AR, Rayes M, Pandey P, Tiwari A, Kansara A, Guthikonda M. The safety and efficacy of coiling multiple aneurysms in the same session. J Neurointerv Surg. 2012;4(1): 27-30. doi: 10.1136/jnis.2009.001974.

31. Lawton MT, Quinones-Hinojosa A, Sanai N, Malek JY, Dowd CF. Combined microsurgical and endovascular management of complex intracranial aneurysms. Neurosurgery. 2008;62(6 Suppl 3):1503-15. doi: 10.1227/01.neu.00003338 14.02649.a0.

32. Strange F, Sivanrupan S, Gruter BE, Rey J, Taeschler D, Fandino J, et al. Fluorescence angiography for evaluation of aneurysm perfusion and parent artery patency in rat and rabbit aneurysm models. J Vis Exp. 2019 Jul 24;(149). doi: 10.3791/ 59782. PMID: 31403621.

33. Hoh BL, Carter BS, Putman CM, Ogilvy CS. Important factors for a combined neurovascular team to consider in selecting a treatment modality for patients with previously clipped residual and recurrent intracranial aneurysms. Neurosurgery. 2003;52(4):732-8. doi: 10.1227/01.neu.0000053209.61909.f2.

34. Choudhri O, Mukerji N, Steinberg GK. Combined endovascular and microsurgical management of complex cerebral aneurysms. Front Neurol.2013;4:108. doi: 10.3389/fneur.2013.00108.

35. Hacein-Bey L, Connolly ES Jr, Mayer SA, Young WL, PileSpellman J, Solomon RA. Complex intracranial aneurysms: combined operative and endovascular approaches. Neurosur- 
gery. 1998;43(6):1304-12. doi: 10.1097/00006123-19981200000020.

36. Rinne J, Hernesniemi J, Niskanen M, Vapalahti M. Management outcome for multiple intracranial aneurysms. Neurosurgery. 1995;36:31-8. doi: 10.1227/00006123-199501000-00003.

37. Inagawa T. Surgical treatment of multiple intracranial aneurysms. Acta Neurochir (Wien). 1991;108:22-9. doi: 10.1007/ BF01407662.
38. Andrews RJ, Spiegel PK. Intracranial aneurysms: age, sex, blood pressure, and multiplicity in an unselected series of patients. J Neurosurg. 1979;51:27-32. doi: 10.3171/jns.1979. 51.1.0027.

39. Inagawa T. Multiple intracranial aneurysms in elderly patients. Acta Neurochir (Wien). 1990;106:119-26. doi.org/10.1007/ BF01809453.

\title{
Sažetak \\ HIBRIDNI MIKROKIRURŠKI I ENDOVASKULARNI PRISTUP U LIJEČENJU VIŠESTRUKIH MOŽDANIH ANEURIZMI: ILUSTRATIVNI PRIKAZ SLUČAJEVA I USPOREDBA S PODACIMA IZ LITERATURE
}

\author{
K. Rotim, V. Kalousek, B. Splavski, S. Tomasović i A. Rotim
}

Suvremeno je liječenje cerebralnih aneurizmi uvelike napredovalo zahvaljujući ekspanziji mikrokirurških i endovaskularnih postupaka koji se odlikuju različitim podobnostima, ali i ograničenjima. Međutim, pojedine je aneurizme ponekad nemoguće uspješno liječiti samo jednom od metoda s obzirom na njihovu specifičnu anatomiju, lokalizaciju, složenost i/ili višestrukost. Upravo su višestruke aneurizme gdjekad podobne za hibridni pristup koji objedinjuje obje navedene metode. Namjera je ovoga rada raspraviti indikacije, mogućnosti i izazove hibridne strategije pri donošenju odluke o obliku liječenja višestrukih intrakranijskih aneurizmi. $U$ radu prikazujemo analizu bolesnika s navedenim aneurizmama u kojih je primijenjen hibridni pristup i raspravljamo o rezultatima i ishodu liječenja uspoređujući ih s podacima iz literature. Oboje se je naših bolesnika uspješno oporavilo nakon provedenog liječenja, kad je nastupila potpuna i stabilna okluzija aneurizme bez znakova ponovne pojave aneurizme i bez komplikacija povezanih s provedenim postupkom, kao i bez trajnog neurološkog deficita. Zaključujemo kako je hibridni pristup preporučena opcija liječenja višestrukih moždanih aneurizmi u slučajevima kada je pojedinačna metoda liječenja nedostatna za osiguravanje zadovoljavajućih rezultata. Ovakav je pristup podoban i siguran kao alternativa rasponu drugih oblika liječenja usmjerenih ka kliničkom poboljšanju i pozitivnom ishodu u bolesnika s rupturiranim i nerupturiranim višestrukim moždanim aneurizmama.

Ključne riječi: Moždana aneurizma, višsstruka; Mikrokirurško liječenje; Endovaskularno liječenje; Hibridni pristup; Ishod liječenja 